\title{
Methane emissions from the upwelling area off Mauritania (NW Africa)
}

\author{
A. Kock ${ }^{1}$, S. Gebhardt ${ }^{1, *}$, and H. W. Bange ${ }^{1}$ \\ ${ }^{1}$ Forschungsbereich Marine Biogeochemie, IFM-GEOMAR, Leibniz-Institut für Meereswissenschaften, \\ Düsternbrooker Weg 20, 24105 Kiel, Germany \\ *now at: Atmospheric Chemistry Dept., Max Planck Institute for Chemistry, Mainz, Germany
}

Received: 4 December 2007 - Published in Biogeosciences Discuss.: 24 January 2008

Revised: 10 June 2008 - Accepted: 3 July 2008 - Published: 5 August 2008

\begin{abstract}
Coastal upwelling regions have been identified as sites of enhanced $\mathrm{CH}_{4}$ emissions to the atmosphere. The coastal upwelling area off Mauritania (NW Africa) is one of the most biologically productive regions of the world's ocean but its $\mathrm{CH}_{4}$ emissions have not been quantified so far. More than 1000 measurements of atmospheric and dissolved $\mathrm{CH}_{4}$ in the surface layer in the upwelling area off Mauritania were performed as part of the German SOPRAN (Surface Ocean Processes in the Anthropocene) study during two cruises in March/April 2005 (P320/1) and February 2007 (P348). During P348 enhanced $\mathrm{CH}_{4}$ saturations of up to $200 \%$ were found close to the coast and were associated with upwelling of South Atlantic Central Water. An area-weighted, seasonally adjusted estimate yielded overall annual $\mathrm{CH}_{4}$ emissions in the range from 1.6 to $2.9 \mathrm{Gg} \mathrm{CH}_{4}$. Thus the upwelling area off Mauritania represents a regional hot spot of $\mathrm{CH}_{4}$ emissions but seems to be of minor importance for the global oceanic $\mathrm{CH}_{4}$ emissions.
\end{abstract}

\section{Introduction}

Atmospheric methane $\left(\mathrm{CH}_{4}\right)$ is a greenhouse gas and plays an important role in the chemistry of the Earth's atmosphere (WMO, 2007; IPCC, 2007). The world's ocean, as a natural source of $\mathrm{CH}_{4}$, plays only a minor role in the global budget of atmospheric $\mathrm{CH}_{4}$. Estimates of the global oceanic $\mathrm{CH}_{4}$ emissions differ considerably and range from $0.4-0.8 \mathrm{Tg} \mathrm{CH}_{4} \mathrm{yr}^{-1}$ for the open ocean (Bates et al., 1996; Kelley and Jeffrey, 2002) up to $11-18 \mathrm{Tg} \mathrm{CH}_{4} \mathrm{yr}^{-1}$ including coastal areas (Bange et al., 1994). Biologically productive coastal regions cover only a small portion of

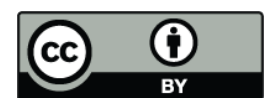

Correspondence to: $\mathrm{H}$. W. Bange (hbange@ifm-geomar.de) the world's ocean, but appear to be sites of significantly enhanced oceanic $\mathrm{CH}_{4}$ emissions (see e.g. Bange, 2006). Coastal upwelling regions such as found in the NW Arabian Sea, the coast off Oregon and off Namibia (SW Africa) have been identified as sites of enhanced $\mathrm{CH}_{4}$ concentrations and emissions, respectively (Owens et al., 1991; Rehder et al., 2002; Monteiro et al., 2006). $\mathrm{CH}_{4}$ emissions from coastal upwelling areas are indirectly linked to high primary productivity which favours $\mathrm{CH}_{4}$ formation during methanogenesis in sinking organic particles and in the sediments (Rehder et al., 2002; Sansone et al., 2001). $\mathrm{CH}_{4}$-enriched subsurface water masses are brought to the surface during the upwelling events providing a pathway to ventilate $\mathrm{CH}_{4}$ from the ocean to the atmosphere. The coastal upwelling area off Mauritania (NW Africa) is one of the most biologically productive regions of the world's ocean but its $\mathrm{CH}_{4}$ emissions have not been quantified so far. Here we present the first study of $\mathrm{CH}_{4}$ in the coastal upwelling area of Mauritania during two cruises during the upwelling seasons in 2005 and 2007. On the basis of more than 1000 measurements of atmospheric and dissolved $\mathrm{CH}_{4}$ in the surface layer we present an area-weighted, seasonally adjusted $\mathrm{CH}_{4}$ flux estimate for the Mauritanian upwelling.

\section{Study site description}

The eastern tropical North Atlantic Ocean is an area with strongly differing hydrographic and biological properties: On the one hand, the Canary and North Equatorial Currents form the eastern part of the North Atlantic Subtropical Gyre which is a zone of low nutrient-supply and thus low primary production (see e.g. Signorini et al., 1999). On the other hand nutrient-rich upwelled water masses feed zones of high biological productivity off the Northwest African coast (Minas et al., 1982).

Published by Copernicus Publications on behalf of the European Geosciences Union. 
Upwelling events off Mauritania are characterised by a pronounced drop in the surface temperatures (here defined as the difference between the temperatures off the coast and the open ocean) of $>-6.5^{\circ} \mathrm{C}$ (Wooster et al., 1976; Speth and Detlefsen, 1982): Surface temperatures of $<17^{\circ} \mathrm{C}$ are typical for upwelled water masses along the coast of Mauritania (Mittelstaedt, 1986). The active upwelling occurs within a narrow $(10-20 \mathrm{~km})$ band along the continental margin as a consequence of offshore Ekman transport due to the trade winds along the Mauritanian coastline (Mittelstaedt, 1986) and shows a seasonality following the shifting of the InterTropical Convergence Zone (ITCZ) throughout the year (Hagen, 2001). In the region between Cap Vert $\left(\sim 15^{\circ} \mathrm{N}\right)$ and Cap Blanc $\left(\sim 21^{\circ} \mathrm{N}\right)$ seasonal upwelling takes place during winter/spring with the southernmost extension in February (Schemainda et al., 1975; Nykjær and Van Camp, 1994; Wooster et al., 1976): On the basis of a compilation of sea surface temperature data from merchant ship observations during the period 1850-1970, Wooster et al. (1976) concluded that upwelling between $12^{\circ}$ and $20^{\circ} \mathrm{N}$ takes places from January through May. With a detailed oceanographic study from 1970-1973, Schemainda et al. (1975) showed that the regional upwelling seasons last from end of November to mid of May (off Cap Vert), from October to June (off Nouakchott, $\sim 18^{\circ} \mathrm{N}$ ) and throughout the year (off Cap Blanc).

Beside the pronounced seasonal variability, the Mauritanian upwelling also shows an interannual variability caused by El Niño-Southern Oscillation (ENSO) events (Roy and Reason, 2001): During warm ENSO events upwelling is weakened and during cold ENSO events (i.e. La Niña conditions) upwelling is intensified. There is a $4-5$ months time lag between the ENSO events and the resulting upwelling anomalies (i.e. wind stress and SST anomalies) off Mauritania (Roy and Reason, 2001).

Two different subsurface water masses have been identified to feed the upwelling (see e.g. Tomczak, 1982; Pastor et al., 2008): North of $21^{\circ} \mathrm{N}$ upwelled waters are mainly influenced by North Atlantic Central Water (NACW) while south of $21^{\circ} \mathrm{N}$ they show properties of South Atlantic Central Water (SACW). The temperature-salinity (T-S) characteristics of NACW and SACW are described by straight lines between the $\mathrm{T} / \mathrm{S}$ points $7^{\circ} \mathrm{C} / 35.0$ and $18^{\circ} \mathrm{C} / 36.7$ (for NACW) and $5^{\circ} \mathrm{C} / 34.3$ and $20^{\circ} \mathrm{C} / 36.0$ (for SACW). This is in line with the definitions of the upper limits of NACW $\left(18.0^{\circ} \mathrm{C} / 36.38\right)$ and SACW $\left(18.0^{\circ} \mathrm{C} / 35.9\right)$ as given by Manríquez and Fraga (1982). Both NACW and SACW are found between 100 and $800 \mathrm{~m}$ water depth off the coast (Tomczak, 1982). SACW is advected by a poleward undercurrent into the Northern Hemisphere and is nutrient enriched compared to the NACW (Minas et al., 1982; Tomczak, 1981; Pastor et al., 2008).

During the coastal upwelling events the formation of cold water filaments (with an average length of $130 \mathrm{~km}$ and an average width of $30 \mathrm{~km}$ ) have been observed off Mauritania (Kostianoy and Zatsepin, 1996). Filaments contribute significantly to the offshore export of the shelf production
(Álvarez-Salgado et al., 2007; Gabric et al., 1993).

Several attempts have been made to decipher characteristic biogeographic or oceanic provinces for the tropical Northeast Atlantic Ocean: On the basis of algal ecology, near-surface circulation patterns and chlorophyll data, Sathyendranath et al. (1995) proposed the province Canary Current (CNRY) which includes both the upwelling areas of NW Africa (off Senegal, Mauritania and Morocco) and the upwelling off Portugal. An oceanic classification was introduced by Hooker et al. (2000) on the basis of T-S data. They defined the Canary Current Upwelling Province (CCUp) from $16^{\circ} \mathrm{N}$ to $20^{\circ} \mathrm{N}$. A more detailed classification based on bathymetry and surface circulation patterns was proposed by Hoepffner et al. (1999) who distinguished three provinces in the tropical NE Atlantic Ocean: Cap Blanc Gyre (CBgy, water depths $>2000 \mathrm{~m}$, Cap Blanc slope (CBsl, water depths 200-2000 m) and Cap Blanc shelf (CBsh, water depths $<200 \mathrm{~m}$ ). The two coastal provinces (CBsl and $\mathrm{CBsh}$ ) extend from $15^{\circ} \mathrm{N}$ to $22^{\circ} \mathrm{N}$ and are therefore comparable with the CCUp province by Hooker et al. (2000) but they are not comparable with the more extended CNRY province by Sathyendranath et al. (1995).

\section{Methods}

The measurements were performed on board the research vessel Poseidon during the cruises P320/1 and P348. The cruise P320/1 was a pilot study of the German SOPRAN (Surface Ocean Processes in the Anthropocene) project and took place from 21 March to 7 April 2005. However, $\mathrm{CH}_{4}$ measurements were performed only from 27 March to 30 March. The cruise P348 was part of the SOPRAN study and took place from 8 to 26 February 2007. During P348 $\mathrm{CH}_{4}$ measurements were performed in the period from 19 to 24 February. The cruise tracks are shown in Fig. 1.

$\mathrm{CH}_{4}$ was determined using a gas chromatograph equipped with a flame ionisation detector. Details of the analytical system are described in Kock (2007) and Bange et al. (1996). Seawater was pumped continuously from a depth of approximately $3 \mathrm{~m}$ into a shower type equilibrator developed by R. F. Weiss (Scripps Institution of Oceanography, La Jolla, $\mathrm{CA})$. Concentrations and resulting saturation values were corrected for the difference between the water temperature at the sea chest and the continuously recorded water temperature in the equilibrator. A series of measurements of seawater and ambient air followed by two standards $(1.779 \pm 0.002$ and $2.543 \pm 0.002 \mathrm{ppm} \mathrm{CH}_{4}$ in synthetic air) were repeated every $26 \mathrm{~min}$ (P320/1) and $22 \mathrm{~min}$ (P348). The gravimetrically prepared gas standards (made by DEUSTE Steininger $\mathrm{GmbH}$, Mühlhausen, Germany) were calibrated against the actual NOAA standard scale (Dlugokencky et al., 2005) in the laboratories of the Max Planck Institute for Biogeochemistry in Jena, Germany. 


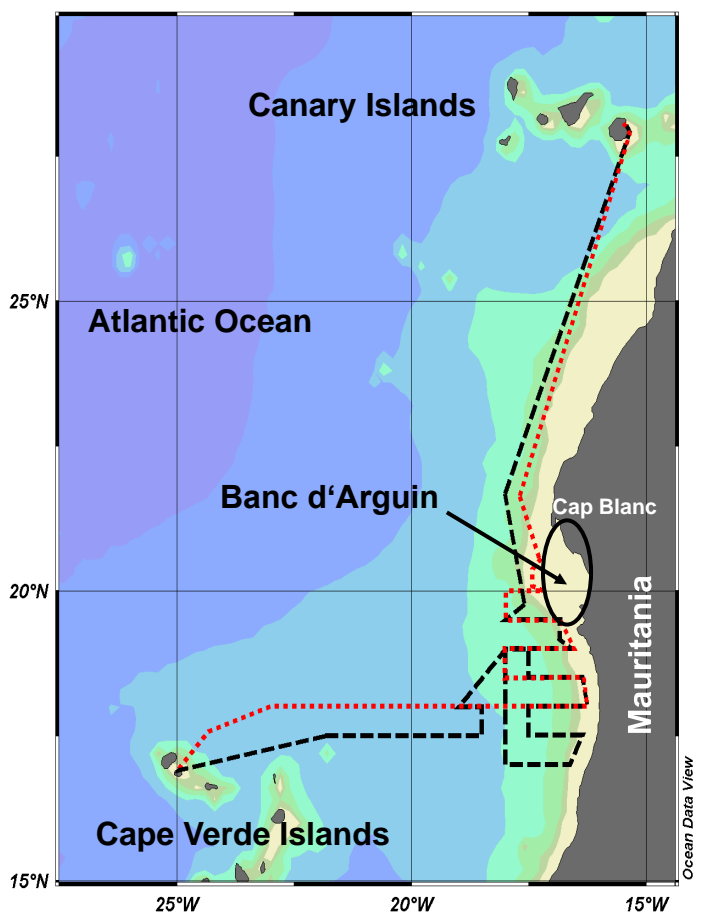

Fig. 1. Cruise tracks of P320/1 (black, March/April 2005) and P348 (red, February 2007) in the eastern tropical North Atlantic Ocean.

The analytical precision, calculated for $\mathrm{P} 320 / 1$ as the ratio of the standard deviation of the atmospheric measurements to the mean atmospheric mole fraction was $\pm 1.1 \%$. The mean relative errors of the $\mathrm{CH}_{4}$ concentrations and saturations, were estimated to $\pm 5 \%$. Saturation values (expressed in $\%$, i.e., $100 \%=$ equilibrium) were calculated by applying the solubility equation of Wiesenburg and Guinasso (1979). Continuous time series of seawater temperature (SST), salinity, and wind speed were obtained from the ship's records. SST and salinity were measured by the ship's thermosalinograph and calibrated against CTD values.

\section{Results and discussion}

The mean atmospheric $\mathrm{CH}_{4}$ dry mole fraction during P320/1 in March 2005 was $1.84 \pm 0.02 \mathrm{ppm} \mathrm{CH}_{4}$ and is in agreement with the monthly mean of $1.821 \mathrm{ppm}$ measured in March 2005 at the NOAA/ESRL atmospheric baseline observatory Izaña on Tenerife $\left(28.3^{\circ} \mathrm{N}, 16.5^{\circ} \mathrm{W}\right.$, elevation $2300 \mathrm{~m}$ ) (Dlugokencky et al., 2007). In contrast to P320/1, the atmospheric $\mathrm{CH}_{4}$ dry mole fractions during P348 in February 2007 were highly variable and ranged from 1.79 to $2.37 \mathrm{ppm}$ (Fig. 2). They are in reasonable agreement with the monthly mean $\mathrm{CH}_{4}$ dry mole fraction of $1.836 \pm 0.017 \mathrm{ppm}$ measured in February 2007 at Izaña (E. Dlugokencky, personal communication). During P348 enhanced $\mathrm{CH}_{4}$ mole fractions were found between $19^{\circ} \mathrm{N}$ and $21^{\circ} \mathrm{N}$. This could result

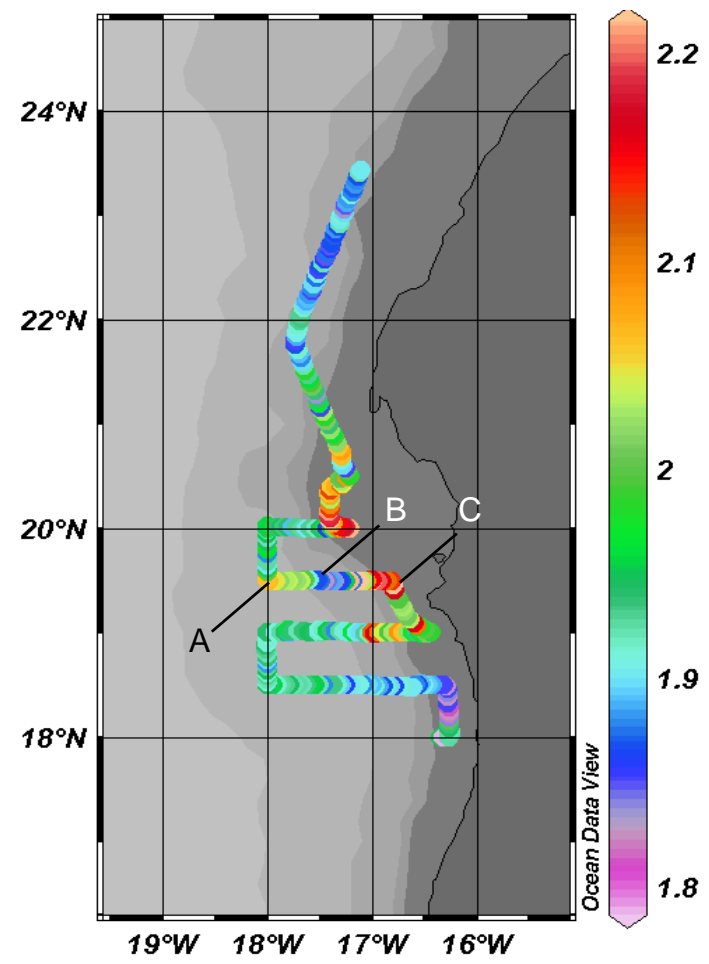

Fig. 2. Atmospheric $\mathrm{CH}_{4}$ dry mole fraction during P348. The capital letters refer to the air mass backward trajectories shown in Fig. 3.

from air masses which became enriched with $\mathrm{CH}_{4}$ while crossing the Banc d'Arguin area as indicated by air mass backward trajectories (Fig. 3). The shallow waters of the Banc d'Arguin ecosystem (water depths between 1-10 m) are very productive and, therefore, the sediments of the Banc d'Arguin should be rich in organic material and favourable for enhanced emissions of $\mathrm{CH}_{4}$. With the assumption that an air mass at $20 \mathrm{~m}$ spent $6 \mathrm{~h}$ over the Banc d'Arguin area before being measured at the ship, the observed atmospheric increase of about $0.7 \mathrm{ppm}$ requires a $\mathrm{CH}_{4}$ surface flux of about $100 \mu \mathrm{mol} \mathrm{h}^{-1} \mathrm{~m}^{-2}$. This seems plausible given the fact that $\mathrm{CH}_{4}$ fluxes from organic-rich tropical coastal environments such as mangroves can be $>1000 \mu \mathrm{molh}^{-1} \mathrm{~m}^{-2}$ (see e.g. Allen et al., 2007; Biswas et al., 2007). Unfortunately, $\mathrm{CH}_{4}$ measurements from the inner Banc d'Arguin are not available.

Backward trajectories for $\mathrm{P} 320 / 1$ indicated that the air masses measured during P320/1 did cross the Banc d'Arguin as well (Quack et al., 2007), however, the distance from the ship positions to the Banc d'Arguin was considerably larger compared to $\mathrm{P} 348$. Thus we speculate that the $\mathrm{CH}_{4}$ source in the Banc d'Arguin area was weaker in 2005. During both cruises we did not find indications that the atmospheric values have been influenced by possible contamination due to $\mathrm{CH}_{4}$ emissions from the ship's diesel engines (Sinha et al., 2003). 


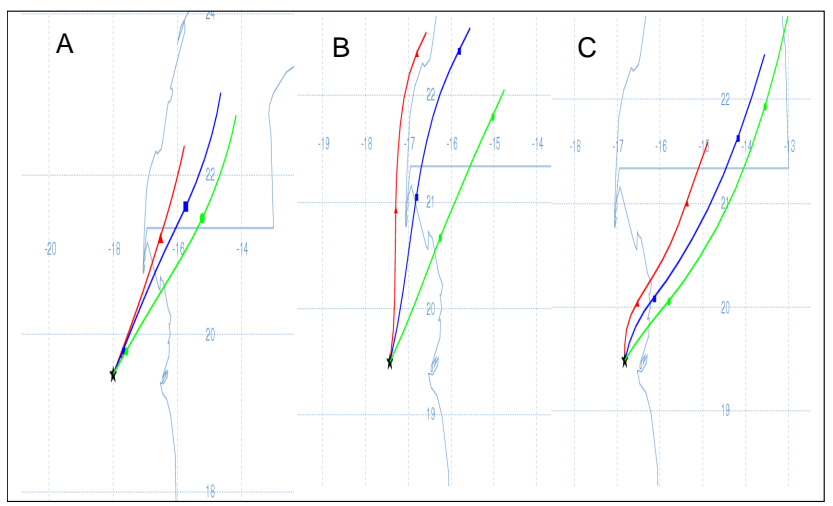

Fig. 3. Selected $12 \mathrm{~h}$ backward air mass trajectories. Trajectories were calculated with the NOAA HYSPLIT on-line transport and dispersion model (Draxler and Rolph, 2003). The starting points and times correspond to the ship's position as depicted with the capital letters in Fig. 2. Red trajectory, $20 \mathrm{~m}$ above sea level (a.s.l.), blue trajectory, $200 \mathrm{~m}$ a.s.1., and green trajectory, $500 \mathrm{~m}$ a.s.1.

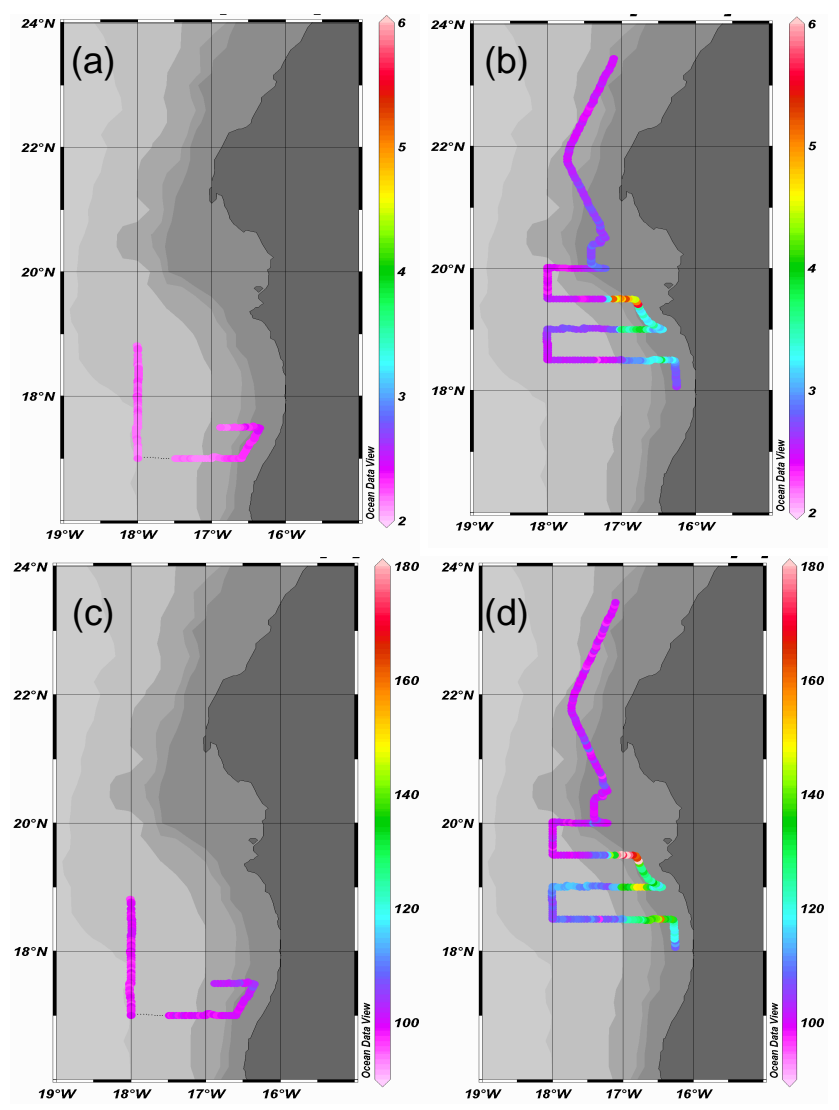

Fig. 4. $\mathrm{CH}_{4}$ concentrations (in $\mathrm{nmol} \mathrm{L}^{-1}$ ) during $\mathrm{P} 320 / 1$ (a) and P348 (b) and $\mathrm{CH}_{4}$ saturations (in \%) during P320/1 (c) and P348 (d).

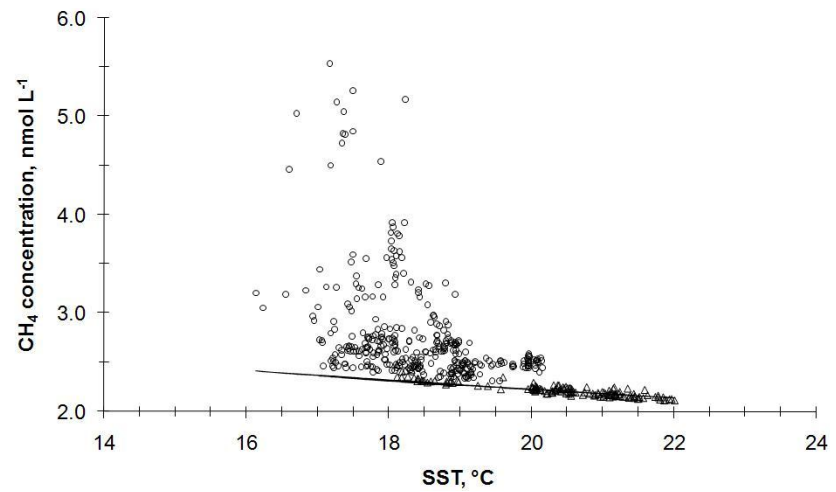

Fig. 5. $\mathrm{CH}_{4}$ concentrations vs. SST. Open circles represent data from P348, open triangles represent data from P320/1. The solid line is the dissolved $\mathrm{CH}_{4}$ equilibrium concentration calculated with an atmospheric $\mathrm{CH}_{4}$ dry mole fraction of $1.83 \mathrm{ppm}$.

In March 2005 dissolved $\mathrm{CH}_{4}$ concentrations were rather uniform and ranged from 2.1 to $2.5 \mathrm{nmol} \mathrm{L}^{-1}$ with saturations close to the equilibrium with the atmosphere (96106\%) (Fig. 4). During P348 in February 2007 dissolved $\mathrm{CH}_{4}$ concentrations were much more variable and ranged from 2.2 to $5.5 \mathrm{nmol} \mathrm{L}^{-1}$. $\mathrm{CH}_{4}$ saturations ranged from $97 \%$ to $200 \%$ (Fig. 4). The majority of low $\mathrm{CH}_{4}$ saturations were found in the western part of the transect at $18.5^{\circ} \mathrm{N}$ and north of $20^{\circ} \mathrm{N}$, whereas significantly enhanced $\mathrm{CH}_{4}$ saturations were mainly found close to the coast between $19^{\circ} \mathrm{N}$ to 19.5 $\mathrm{N}$ (Fig. 4).

Conrad and Seiler (1988) measured $\mathrm{CH}_{4}$ surface saturations ranging from about $108 \%$ to about $155 \%$ during a straight transect from Cap Blanc to Cap Vert during the upwelling season in January 1979. Their data are in agreement with the data from our study (see above). Moreover, our open ocean data are in agreement with $\mathrm{CH}_{4}$ concentrations (about $2 \mathrm{nmol} \mathrm{L}^{-1}$ ) measured along $20^{\circ} \mathrm{W}$ by Rhee (2000). However, our open ocean saturations are lower than those observed by Forster et al. (2008), who found a mean $\mathrm{CH}_{4}$ saturation concentration of $156 \pm 29 \%$ (corresponding to a mean $\mathrm{CH}_{4}$ concentration of $3 \pm 0.7 \mathrm{nmol} \mathrm{L}^{-1}$ ) in the surface layer at three stations off Mauritania along $18^{\circ} \mathrm{W}$ during the non-upwelling season in September 2003. This discrepancy might results from seasonal and/or interannual differences (see section Study site description).

Figure 5 shows a plot of SST vs. $\mathrm{CH}_{4}$ concentrations to illustrate the role of upwelling processes. It is obvious that the enhanced $\mathrm{CH}_{4}$ saturations during P348 were associated with low SST indicating upwelled water masses. The enhanced $\mathrm{CH}_{4}$ concentrations in the upwelled water masses are most probably caused by methanogenesis in anoxic microniches of sinking organic particles and/or by methanogenesis in the shelf sediments (Rehder et al., 2002; Sansone et al., 2001) which leads to an accumulation of $\mathrm{CH}_{4}$ before the water masses are brought to the surface. However, production of 
Table 1. $\mathrm{CH}_{4}$ emission estimate.

\begin{tabular}{lcccc}
\hline & $\begin{array}{c}\text { Area }^{\mathrm{a}} \\
10^{12} \mathrm{~m}^{-2}\end{array}$ & $\begin{array}{c}\text { Mean flux density } \\
\text { pmol m}^{-2} \mathrm{~s}^{-1}\end{array}$ & \multicolumn{2}{c}{$\begin{array}{c}\text { Emissions }^{\mathrm{b}} \\
\mathrm{Gg}\end{array}$} \\
\hline & & & Upwelling $^{\mathrm{c}}$ & Non-upwelling \\
\hline Cape Blanc shelf & 0.11 & $11.3 / 19.1$ & $0.3 / 0.4$ & $0.1^{\mathrm{d}} / 0.3^{\mathrm{d}}$ \\
Cape Blanc slope & 0.10 & $10.3 / 18.1$ & $0.2 / 0.4$ & $0.1^{\mathrm{d}} / 0.2^{\mathrm{d}}$ \\
Cape Blanc gyre & 0.37 & $4.55 / 8.47$ & - & $0.8^{\mathrm{e}} / 1.6^{\mathrm{e}}$ \\
Total & 0.58 & - & $0.6 / 0.8$ & $1.0 / 2.1$ \\
\hline
\end{tabular}

${ }^{a}$ Areas were taken from Hoepffner et al. (1999).

${ }^{\mathrm{b}}$ First value stands for flux densities and emissions based on Liss and Merlivat (1986), second value stands for flux densities and emissions based on Wanninkhof (1992).

${ }^{c}$ We assumed a mean duration of 5 months for the upwelling season (Wooster et al., 1976).

${ }^{\mathrm{d}}$ We assumed a mean duration of 7 months for the non-upwelling season (Wooster et al., 1976). The emissions were calculated on the basis of the mean flux densities for the Cap Blanc gyre province given in the third column.

e Calculated for a 12 months period.

$\mathrm{CH}_{4}$ by zooplankton grazing could contribute to the $\mathrm{CH}_{4}$ accumulation as well (De Angelis and Lee, 1994).

The hydrographic properties of the subsurface waters together with $\mathrm{CH}_{4}$ saturations are shown in Fig. 6. All data points lie between the T/S lines of NACW and SACW (for a definition see section Study site description), suggesting that they were resulting from mixing of the two water masses. While the water with enhanced $\mathrm{CH}_{4}$ saturations (i.e. those found close to Banc d'Arguin) show properties close to the SACW, water with $\mathrm{CH}_{4}$ saturations around $100 \%$ were associated with NACW. Thus, we conclude that the observed enhanced $\mathrm{CH}_{4}$ concentrations mainly originated from water masses with a major contribution of SACW. A possible contribution of $\mathrm{CH}_{4}$ enriched water masses originating from the Banc d'Arguin characterised by surface salinities of $>37$ (Mittelstaedt, 1986; Peters, 1976; Tomczak, 1981) is not visible in Fig. 6 and thus seems to be unlikely at the time of our cruises.

\section{$5 \mathrm{CH}_{4}$ air-sea exchange}

The $\mathrm{CH}_{4}$ exchange flux density, $F$ in pmol m${ }^{-2} \mathrm{~s}^{-1}$, can be parameterized as $F=k_{w}\left(C_{w}-C_{a}\right)$, where $k_{w}$ is the gas transfer coefficient, $C_{w}$ is the seawater concentration, and $C_{a}$ is the equilibrium water concentration calculated using the corresponding atmospheric dry mole fraction. To calculate $k_{w}$, we used the tri-linear $k_{w}$ /wind speed relationship from Liss and Merlivat (1986) (hereinafter referred to as LM86) or, alternatively, the quadratic $k_{w}$ /wind speed relationship established by Wanninkhof (1992) (hereinafter referred to as W92). The coefficients $k_{w}$ were adjusted by multiplying with $(S c / 600)^{-n}\left(n=2 / 3\right.$ for wind speeds $\leq 3.6 \mathrm{~m} \mathrm{~s}^{-1}$ and $n=0.5$ for wind speeds $>3.6 \mathrm{~m} \mathrm{~s}^{-1}$ ) for LM86 and $(S c / 660)^{-0.5}$ for W92. $S c$ is the Schmidt number for $\mathrm{CH}_{4}$ and was calculated using empirical equations for the kinematic viscosity of sea-

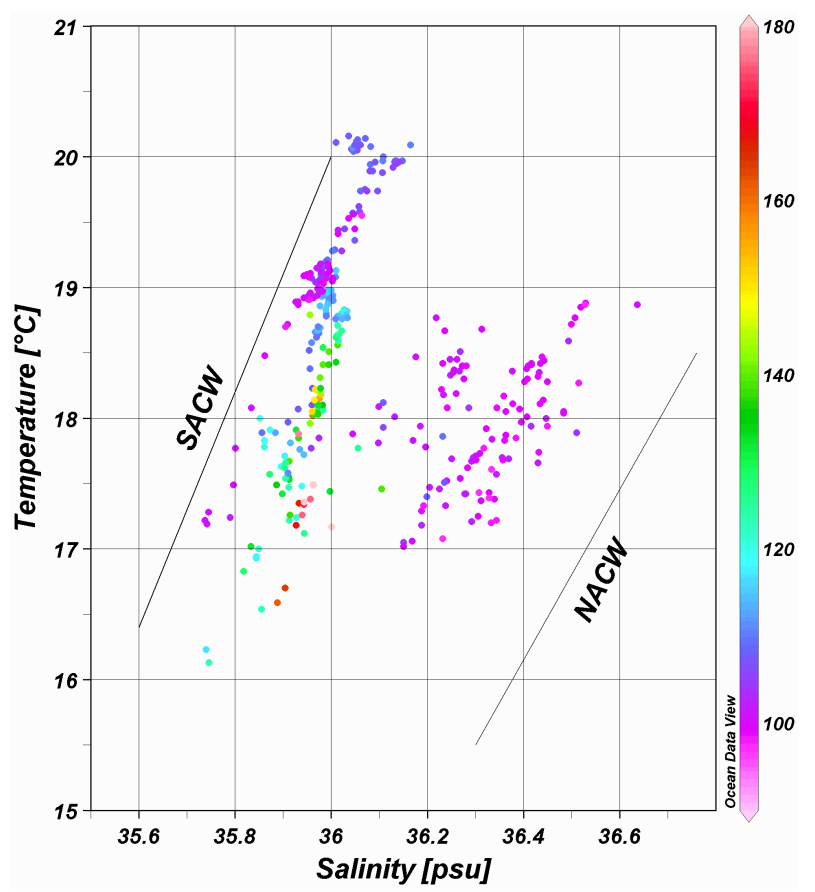

Fig. 6. T/S diagram and $\mathrm{CH}_{4}$ saturations from the P348. The T/S curves of the predominant water masses, NACW and SACW, are shown as straight lines (Tomczak and Godfrey, 2003).

water (Siedler and Peters, 1986) and the diffusivity of $\mathrm{CH}_{4}$ in water (Jähne et al., 1987). The measured wind speeds were normalised to $10 \mathrm{~m}$ height by using the relationship of Garratt (1977).

In order to estimate the $\mathrm{CH}_{4}$ emissions from the Mauritanian upwelling we pooled our data according to the three provinces suggested by Hoepffner et al. (1999): CBgy, CBsl and CBsh (see section Study site description). For the seasonality we adopted the periods given in Wooster et 
al. (1976): 5 months and 7 months for the upwelling and nonupwelling seasons, respectively (see Study Site description). Then we calculated the mean flux densities and emissions for the three provinces (Table 1). The total $\mathrm{CH}_{4}$ emissions during the upwelling season $\left(0.5-0.8 \mathrm{Gg} \mathrm{CH}_{4}\right)$ are comparable with the emissions from the coastal upwelling in the NW Arabian Sea $\left(0.5-0.9 \mathrm{Gg} \mathrm{CH}_{4}\right.$, calculated for a 4 months upwelling period by Bange et al. (1998). The annual $\mathrm{CH}_{4}$ emissions, calculated as the sum of the individual emissions during the upwelling and the non-upwelling seasons, range from 1.6 to $2.9 \mathrm{Gg} \mathrm{CH}_{4}$ (Table 1) representing about $0.2-0.7 \%$ of the global open ocean emissions of $400-800 \mathrm{Gg} \mathrm{yr}^{-1}$ (Bates et al., 1996; Kelley and Jeffrey, 2002). Thus, the upwelling area off Mauritania represents a regional hot spot but is of minor importance for the global oceanic $\mathrm{CH}_{4}$ emissions. The emission estimates presented in Table 1, however, strongly depend on the choice of the province classification and seasonality. For example, when adopting a duration of 9 months for the upwelling season, as suggested by Schemainda et al. (1975) for $18^{\circ} \mathrm{N}$, the total annual $\mathrm{CH}_{4}$ emissions yield $1.8-3.2 \mathrm{Gg}$.

As shown by Roy and Reason (2001), the upwelling intensity off Mauritania as indicated by SST anomalies in spring/summer is positively correlated with the bimonthly multivariate ENSO index (MEI) for November/December of the preceding year: Negative (positive) MEI indicate La Niña (El Niño) conditions with intensified (weakened) upwelling (Roy and Reason, 2001). The December/November MEI for 2004 and 2006 were +0.68 and +0.97 , respectively (MEI data computed by Klaus Wolter, http://www.cdc.noaa.gov/people/ klaus.wolter/MEI/table.html, updated 6 May 2008). Thus, we conclude that the upwelling during the cruises P320/1 and P348 was not intensified indicating that our $\mathrm{CH}_{4}$ emission estimate might be conservative. We speculate that $\mathrm{CH}_{4}$ in years with intensified upwelling might be higher.

Acknowledgements. We are indebted to all participants of P320/1 and P348 for their excellent collaboration and we acknowledge the invaluable support of the captain and crew of R/V Poseidon. We thank Imke Goertz for building the $\mathrm{CH}_{4}$ pump rack and we thank Armin Jordan for the calibration of our standard gases. Ed Dlugokencky generously made unpublished $\mathrm{CH}_{4}$ data available for us. We thank the authorities of Mauritania for permission to work in their exclusive economic zone. The authors gratefully acknowledge the NOAA Air Resources Laboratory (ARL) for the provision of the HYSPLIT transport and dispersion model used in this publication. Two anonymous reviewer provided helpful comments. S. G. acknowledges the financial support by grants provided by A. Körtzinger and A. Eisenhauser. Cruise P320/1 was supported by the Deutsche Forschungsgemeinschaft (DFG) with grant BA1990/6. Cruise P348 was part of the joint project SOPRAN and was funded by Bundesministerium für Bildung und Forschung (BMBF) with grant 03F0462A. This work was supported by the Forschungsbereich Marine Biogeochemie of IFM-GEOMAR, Kiel.

Edited by: T. R. Christensen

\section{References}

Allen, D. E., Dalal, R. C., Rennenberg, H., Meyer, R. L., Reeves, S., and Schmidt, S.: Spatial and temporal variation of nitrous oxide and methane flux between subtropical mangrove sediments and the atmosphere, Soil Biol. Biochem., 39, 622-631, 2007.

Álvarez-Salgado, X. A., Arístegui, J., Barton, E. D., and Hansell, D. A.: Contribution of upwelling filaments to offshore carbon export in the subtropical Northeast Atlantic Ocean, Limnol. Oceanogr., 52, 1287-1292, 2007.

Bange, H. W., Bartell, U. H., Rapsomanikis, S., and Andreae, M. O.: Methane in the Baltic and North Seas and a reassessment of the marine emissions of methane, Global Biogeochem. Cy., 8, 465-480, 1994.

Bange, H. W., Rapsomanikis, S., and Andreae, M. O.: The Aegean Sea as a source of atmospheric nitrous oxide and methane, Mar. Chem., 53, 41-49, 1996.

Bange, H. W., Ramesh, R., Rapsomanikis, S., and Andreae, M. O.: Methane in the surface waters of the Arabian Sea, Geophys. Res. Lett., 25, 3547-3550, 1998.

Bange, H. W.: Nitrous oxide and methane in European coastal waters, Estuarine and Coastal Shelf Science, 70, 361-374, 2006.

Bates, T. S., Kelly, K. C., Johnson, J. E., and Gammon, R. H.: A reevaluation of the open ocean source of methane to the atmosphere, J. Geophys. Res., 101, 6953-6961, 1996.

Biswas, H., Mukhopadhyay, S. K., Sen, S., and Jana, T. K.: Spatial and temporal patters of methane dynamics in the tropical mangrove dominated estuary, NE coast of Bay of Bengal, India, J. Mar. Syst., 68, 55-64, 2007.

Conrad, R. and Seiler, W.: Methane and hydrogen in seawater (Atlantic Ocean), Deep-Sea Res., 35, 1903-1917, 1988.

De Angelis, M. A. and Lee, C.: Methane production during zooplankton grazing on marine phytoplankton, Limnol. Oceanogr., 39, 1298-1308, 1994.

Dlugokencky, E. J., Myers, R. C., Lang, P. M., Masarie, K. A., Crotwell, A. M., Thoning, K. W., Hall, B. D., Elkins, J. W., and Steele, L. P.: Conversion of NOAA atmospheric dry air $\mathrm{CH}_{4}$ mole fractions to a gravimetrically prepared standard scale, J. Geophys. Res., 110, D18306, doi:10.1029/2005JD006035, 2005.

Dlugokencky, E. J., Lang, P. M., and Masarie, K. A.: Atmospheric methane dry air mole fractions from the NOAA ESRL Carbon Cylce Cooperative Global Air Sampling Network, 19832006, version 2007-07-31, ftp://ftp.cmdl.noaa.gov/ccg/ch4/flask/ month, 2007.

Draxler, R. R. and Rolph, G. D.: HYSPLIT (HYbrid SingleParticle Lagrangian Integrated Trajectory) model access via NOAA ARL READY website http://www.arl.noaa.gov/ready/ hysplit4.html, NOAA Air Resources Laboratory, Sliver Spring, MD, USA, 2003.

Forster, F. G., Upstill-Goddard, R. C., and Uher, G.: Nitrous oxide and methane in the Atlantic Ocean between $50^{\circ} \mathrm{N}$ and $52^{\circ} \mathrm{S}$ : Latitudinal distribution and sea-to-air flux, Deep-Sea Res. II, in press, 2008.

Garratt, J. R.: Review of the drag coefficients over oceans and continents, Mon. Weather Rev., 105, 915-929, 1977.

Gabric, A. J., Gracia, L., Van Camp, L., Nykjær, L., Eifler, W., and Schrimpf, W.: Offshore export of shelf production in the Cape Blanc (Mauritania) giant filament as derived from Coastal Zone Color Scanner imagery, J. Geophys. Res., 98, 4697-4712, 1993.

Hagen, E.: Northwest African upwelling scenario, Oceanologica 
Acta, 24, S113-S127, 2001.

Hoepffner, N., Sturm, B., Finenko, Z., and Larkin, D.: Depthintegrated primary production in the eastern tropical and subtropical North Atlantic basin from ocean colour imagery, Int. J. Remote Sens., 20, 1435-1456, 1999.

Hooker, S. B., Rees, N. W., and Aiken, J.: An objective methodology for indentifying oceanic provinces, Prog. Oceanogr., 45, 313-338, 2000.

IPCC: Climate Change 2007: The Physical Science Basis, Contribution of Working Group I to the Fourth Assessment Report of the Intergovernmental Panel on Climate Change, Cambridge University Press, Cambridge, UK and New York, NY, USA, 996 pp., 2007.

Jähne, B., Heinz, G., and Dietrich, W.: Measurements of the diffusion coefficients of sparingly soluble gases in water, J. Geophys. Res., 92, 10 767-10 776, 1987.

Kelley, C. A. and Jeffrey, W. H.: Dissolved methane concentration profiles and air-sea fluxes from $41^{\circ} \mathrm{S}$ to $27^{\circ} \mathrm{N}$, Global Biogeochem. Cy., 16, 1040, doi:10.1029/2001GB001809, 2002.

Kock, A.: Methane measurements in selected ocean areas: Eastern tropical North Atlantic Ocean and southwestern Labrador Sea, Diploma thesis, Kiel University, Kiel, 106 pp., 2007.

Kostianoy, A. G. and Zatsepin, A. G.: The West African coastal upwelling filaments and cross-frontal water exchange conditioned by them, J. Mar. Syst., 7, 349-359, 1996.

Liss, P. S. and Merlivat, L.: Air-sea exchange rates: introduction and synthesis, in: The Role of Air-Sea Exchange in Geochemical Cycling, edited by: Buat-Ménard, P., Series C: Mathem. \& Phys. Sciences, D. Reidel Publishing Company, Dordrecht, 113-127, 1986.

Manríquez, M. and Fraga, F.: The distribution of water masses in the upwelling region off Northwest Africa in November, Rapp. P.-v. Réun. Cons. Int. Explor. Mer, 180, 39-47, 1982.

Minas, H. J., Codispoti, L. A., and Dugdale, R. C.: Nutrients and primary production in the upwelling region off Northwest Africa, Rapp. P.-V. Réun. Cons. Int. Explor. Mer, 180, 148-182, 1982.

Mittelstaedt, E.: Upwelling regions, in: Landoldt-Börnstein, New Series, Vol. 3, Oceanography, edited by: Sündermann, J., Springer Verlag, Berlin, 135-166, 1986.

Monteiro, P. M. S., Van der Plas, A., Mohrholz, V., Mabille, E., and Pascall, A.: Variability of natural hypoxia and methane in coastal upwelling system: Oceanic physics or shelf biology?, Geophys. Res. Lett., 33, L16614, doi:10.1029/2006GL026234, 2006.

Nykjær, L. and Van Camp, L.: Seasonal and interannual variability of coastal upwelling along northwest Africa and Portugal from 1981 to 1991, J. Geophys. Res., 99, 14 197-14 207, 1994.

Owens, N. J. P., Law, C. S., Mantoura, R. F. C., Burkill, P. H., and Llewellyn, C. A.: Methane flux to the atmosphere from the Arabian Sea, Nature, 354, 293-296, 1991.

Pastor, M. V., Pelegrí, J. L., Hernández-Guerra, A., Font, J., Salat, J., and Emelianov, M.: Water and nutrient fluxes off Northwest Africa, Cont. Shelf Res., 28, 915-936, 2008.

Peters, H.: The spreading of water masses of the Banc d'Arguin in the upwelling area off the northern Mauritanian coast, Meteor Forschung-Ergebnisse A, 18, 78-100, 1976.

Quack, B., Atlas, E., Petrick, G., and Wallace, D. W. R.: Bromoform and dibromomethane above the Mauritanian upwelling: Atmospheric distributions and oceanic emissions, J. Geophys. Res., 112, D09312, doi:10.1029/2006JD007614, 2007.
Rehder, G., Collier, R. W., Heeschen, K., Kosro, P. M., Barth, J., and Suess, E.: Enhanced marine $\mathrm{CH}_{4}$ emissions to the atmosphere off Oregon caused by coastal upwelling, Global Biogeochem. Cy., 16, 1081, doi:10.1029/2000GB001391, 2002.

Rhee, T. S.: The process of air-water gas exchange and its application, $\mathrm{PhD}$, Office of Graduate Studies, Texas A\&M University, College Station, 272 pp., 2000.

Roy, C. and Reason, C.: ENSO related modulation of the coastal upwelling in the eastern Atlantic, Prog. Oceanogr., 49, 245-255, 2001.

Sansone, F. J., Popp, B. N., Gasc, A., Graham, A. W., and Rust, T. M.: Highly elevated methane in the eastern tropical North Pacific and associated isotopically enriched fluxes to the atmosphere, Geophys. Res. Lett., 28, 4567-4570, 2001.

Sathyendranath, S., Longhurst, A., Caverhill, C. M., and Platt, T. Regionally and seasonally differentiated primary production in the North Atlantic, Deep-Sea Res. I, 42, 1773-1802, 1995.

Schemainda, R., Nehring, D., and Schulz, S.: Ozeanologische Untersuchungen zum Produktionspotential der nordwestafrikanischen Wasserauftriebsregionen 1970-1973, Geodätische und Geophysikalische Veröffentlichungen Reihe IV, 1-88, 1975.

Siedler, G. and Peters, H.: Properties of sea water, in: Oceanography, edited by: Sündermann, J., Landolt-Börnstein, New Series, Springer Verlag, Berlin, 233-264, 1986.

Signorini, S. R., Murtugudde, R. G., McClain, C. R., Christian, J. R., Picaut, J., and Busalachhi, A. J.: Biological and physical signatures in the tropical and equatorial Atlantic, J. Geophys. Res., 104, 18 367-18382, 1999.

Sinha, P., Hobbs, P. V., Yokelson, R. J., Christian, T. J., Kirchstetter T. W., and Bruintjes, R.: Emissions of trace gases and particles from two ships in the southern Atlantic Ocean, Atmos. Environ., 37, 2139-2148, 2003.

Speth, P. and Detlefsen, H.: Meteorological influences on upwelling off Northwest Africa, Rapp. P-v. Réun. Cons. Int. Explor. Mer, 180, 29-34, 1982.

Tomczak Jr., M.: An analysis of mixing in the frontal zone of South and North Atlantic Central Water off North-West Africa, Prog. Oceanogr., 10, 173-192, 1981.

Tomczak, M.: The distribution of water masses at the surface as derived from T-S diagram analysis in the CINECA area, Rapp. P.-v. Réun. Cons. Int. Explor. Mer, 180, 48-49, 1982.

Tomczak, M. and Godfrey, J. S.: Regional oceanography: An introduction, 2nd Ed., Daya Publishing House, Delhi, India, 391 pp., 2003.

Wanninkhof, R.: Relationship between wind speed and gas exchange over the ocean, J. Geophys. Res., 97, 7373-7382, 1992.

Wiesenburg, D. A. and Guinasso Jr., N. L.: Equilibrium solubilities of methane, carbon monoxide, hydrogen in water and seawater, J. Chem. Eng. Data, 24, 356-360, 1979.

WMO: Scientific assessment of ozone depletion: 2006, WMO, World Meteorological Organization, Geneva, Switzerland, 572 pp., 2007.

Wooster, W. S., Bakun, A., and McLain, D. R.: The seasonal upwelling cycle along the eastern boundary of the North Atlantic, J. Mar. Res., 34, 131-141, 1976. 